\title{
Locating Ourselves and Our Work
}

\author{
Eli Goldblatt
}

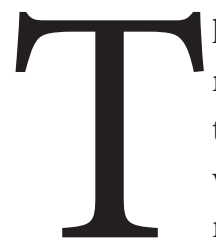

he essays collected for the inaugural issue of Literacy in Composition Studies give me great hope for our discipline. They open rich lines of conversation and suggest that the field commonly called composition/rhetoric or rhet/comp will be served well by the new journal. I like the way Kate Vieira reaches back to re-imagine and recast the old question about the "consequences of literacy," and I value Kathryn Flannery's warning that we must "resist romanticizing either everyday literacies or schooled literacies." In a similar vein, Brenda Glascott's essay on keywords helps us to recognize the dangers of our histories and unexamined vocabularies, cautioning us to avoid linguistic traps that either foreclose valuable avenues for research because of our allegiances to certain parts of the field and wariness of colleagues who identify differently. Scholars in composition, rhetoric, and literacy have been hugely productive in the last thirty years, but our growing sophistication of method and concept can also lead to specialized styles that harden into academic warrens that seal vital intellectual projects off from one another.

Both Graff and Horner emphasize and interrogate the term "location" in our shared work, and I would like to linger first on that term. I do think, with Graff, that status has subtly shaped and sometimes deformed the growth of our collective research choices. For example, I have always felt that we should have continued the fruitful collaboration with cognitive psychology initiated by Linda Flower and John Hayes, but such work would certainly have made it difficult for assistant professors to get tenure in English departments. In the same way, the split Horner identifies between research in English-based composition (primarily focused on texts) and education (the social science of practice in instruction) has something to do with the low opinion most literature faculty have of colleagues who train teachers. Even the divisions Glascott identifies-between those who key on rhetoric and those who use other terms with perhaps less "gravitas"-may have more to do with who one wishes to align with on a faculty than what work one most wishes to pursue. As Vieira usefully notes about immigrants' use of writing, the materiality of literacy "shifts the focus from identity to identification." After all, in the early days of comp/rhet every practitioner was something of an undocumented worker (you wrote your dissertation on The Great Gatsby?), venturing out into vineyards where the toil was not only poorly paid and dangerous but despised to boot. Despite our complaints today, at least those on tenure lines in the field are far less likely to be in quite so compromised a position, yet labor inequities and status issues remain a major legacy of writing studies.

But what I most want to point out is that we almost always study "literacies" within the framework of higher education, and usually within the traditions of the research university. Even those of us who call our work "community literacy" and choose to focus on school/college partnerships, literacy events in community centers or prisons, or other settings outside traditional classrooms, are often rooted in 
English or education departments (whether our loads are $2 / 2$ or 5/5). Things literate look very different if you're trying to run a local GED program, writing grants, developing curriculum, or dealing with boards. As Horner points out, the pesky stain of autonomy often won't come out in the wash no matter how many ways you rename, re-spatialize, or re-temporize literacy in the laundromat of educational innovation. Yet, when even bad schools in a neighborhood close-as it looks like at least five K-8 schools around my university will in the next year-we want to take some kind of stand and say: "No! You can't do this to our kids, teachers, janitors, secretaries, crossing guards." What will we as scholars of literacy have to say? Where will we be when urban kids who are just as bright as the ones in the suburbs are shipped off to overcrowded schools in different neighborhoods for the sake of systemic efficiency? Of course I'm being reductive and alarmist, but really situations are far worse than I'm painting them, because I haven't even mentioned the guns and drugs on the corners or the growing American consensus that many people just might not "need" college after all.

This is of course not to say every aspect of our work isn't important. Actually, I think we have developed some valuable collective wisdom, and scholars in various parts of our field are poised to take new stock of what we know and hold ourselves responsible for the social positions we have won. I take it, again, that Vieira's invocation of the old "consequences" debate represents this impulse, and I fully expect the new journal will be a site for such a gathering of tribes. This leads me to Morris Young's article. I can't get over my own penchant for seeing literacy as human behavior always nested within relationships. It's not just that, like Young, my own professional life was influenced by a long association with Deb Brandt, my dissertation advisor when I was the first Wisconsin comp/rhet grad student. I respond to his piece because of his reminder that a given scholar's life is informed not only by the "grand narratives of scholarship" but "the little narratives of personal touchstones." This may sound sentimental-I'm quite willing to live with that-but I'm also heeding Horner's fierce analysis of autonomy's inexorable logic. To the extent that we remember this is a human-made world, one that needs to be re-imagined regularly lest we find ourselves frozen among reified tombstones, we have a hope of resisting the regimenting logic of institutional life. I grew up in the army, where rank is worn on sleeve and shoulder. On an army post, you wait for orders even while you try to do your job right, and all too often universities remind me of military bases. It's the little narratives that keep us refreshed in the face of habitus. 


\section{WORKS CITED}

Flannery, Kathryn. “Babies and Bath Water." Literacy in Composition Studies 1.1 (2013): n. pag. Web.

Glascott, Brenda. “ Constricting Keywords: Rhetoric and Literacy in our History of Writing." Literacy in Composition Studies 1.1 (2013): n. pag. Web.

Graff, Harvey. “The Legacies of Literacy Studies." Literacy in Composition Studies 1.1 (2013): n. pag. Web.

Horner, Bruce. "Ideologies of Literacy, “Academic Literacies,"and Composition Studies." Literacy in Composition Studies 1.1 (2013): n. pag. Web.

Vieira, Kate. "On the Social Consequences of Literacy." Literacy in Composition Studies 1.1 (2013): n. pag. Web.

Young, Morris. "Sponsoring Literacy Studies." Literacy in Composition Studies 1.1 (2013): n. pag. Web. 